\title{
Anti-Toxic and Anti-Carcinogenic Activities of the Trunk Bark of Sarcocephalus Pobeguinii
}

\author{
Ousmane Keita ${ }^{1 *}$, Huguette Agnaniet ${ }^{2}$, Rokia Sanogo ${ }^{3}$, Balla Dianka ${ }^{4}$ \\ ${ }^{1}$ Department of Biological engineering of Institute of Applied Sciences (ISA) -University of Sciences, Technics \\ and Technologies of Bamako - Mali \\ ${ }^{2}$ Laboratory of Natural Products and Organometallic Synthesis (LASNSOM) - Faculty of Sciences of University \\ of Sciences and Technics of Masuku. Franceville, Gabon. \\ ${ }^{3}$ Laboratory of Pharmacognosy of Faculty of Pharmacy - University of Sciences, Technics and Technologies of \\ Bamako (USTTB) - Mali \\ Laboratory of Networks and Telecommunications. Institute of Applied Sciences of the University of Sciences, \\ Technics and Technologies of Bamako (USTTB) - Bamako, Mali.
}

*Corresponding Author: Ousmane Kéita, Department of Biological engineering of Institute of Applied Sciences (ISA) -University of Sciences, Technics and Technologies of Bamako - Mali

\begin{abstract}
:
Background

Sarcocephalus pobeguinii, because of these virtues, is used in food as well as in therapy. The works noted in the literature concern both total extracts or different organs demonstrating antimalarial, antibacterial, antibiotic and antioxidant properties. The evaluation of toxicity is based on adequate qualitative or quantitative studies. Toxicity can be assessed on epidemiological, experimental in vivo, in vitro and theoretical modelling studies.
\end{abstract}

Objective

The purpose of this study is to evaluate anti-toxic and anti-carcinogenic of trunk bark of Sarcocephalus pobeguinii.

\section{Method}

$10 \mathrm{~g}$ of powder from the trunk bark of Sarcocephalus pobeguinii was introduced in $100 \mathrm{~mL}$. After lyophilization of the extract, the single dose of $2000 \mathrm{mg} / \mathrm{kg}$ of Sarcocephalus pobeguinii was administered to 5 male and female mice and their behaviour was observed for 1 day. The $0 \mathrm{mg} / \mathrm{kg}, 10 \mathrm{mg} / \mathrm{kg}, 50 \mathrm{mg} / \mathrm{kg}$ and 100 $m g / k g$ doses of the extract were prepared and administered daily to 4 male and female rats per batch for 45 and 90 days. At the end of each experiment, the rats were sacrificed and ALT and AST levels were determined. Doses of $1 \mathrm{mg} / \mathrm{kg}$ and $0.5 \mathrm{mg} / \mathrm{kg}$ of the extract were tested in vitro on MCF-7 cancer cells. Results

The mortality rate of $2000 \mathrm{mg} / \mathrm{kg}$ was $0 \%$. The weight of female rats was decreased by $42.64 \%$ at $100 \mathrm{mg} / \mathrm{kg}$. The increase in ALT activity at $50 \mathrm{mg} / \mathrm{kg}$ was $44.95 \%$ and $100 \mathrm{mg} / \mathrm{kg}$ (43.92\%) while the increase in ALT activity was $59.68 \%$. Percent survival of MCF-7 cells was $120 \%$ at $1 \mathrm{mg} / \mathrm{kg}$.

\section{Conclusion}

Sarcocephalus pobeguinii is no toxic, no carcinogenic and requires further studies.

Keywords : Sarcocepahalus pobeguinii, toxicity, cancer

\section{INTRODUCTION}

Toxicity is the measure of a substance's ability to cause adverse and unhealthy effects on all life forms. It can be conducted on an animal, a bacterium or plant, or a substructure of an organism such as the liver $[1,2]$.

The toxicity assessment is based on adequate non-measurable or measurable studies. Depending on the duration of exposure of the organism to the administered substance, a distinction is made between acute toxicity, subacute or (short-term) toxicity, sub chronic toxicity and chronic toxicity [3]. 
In sub-Saharan Africa, cancer now accounts for $10 \%$ to $20 \%$ of the chronic pathologies observed. It primarily affects women between 45 and 55 years of age. The "classic" cancers of the breast, cervix and uterus for women and prostate for men are the most common. But Africa also produces its own specificities. Published estimates predict a $45 \%$ increase in mortality by 2025 [4].

Because of the high cost of treatment and the inaccessibility of treatment centers, populations resort to medicinal plants while being more or less unaware of their toxicity. Sarcocephalus pobeguinii (syn. Nauclea pobeguinii) is commonly used in traditional medicine. In Benue State, Nigeria, Sarcocephalus pobeguinii stem bark is boiled and administered orally to treat abdominal pain and stomach ache [5]. In Guinea Conakry, leaves and bark of Sarcocephalus pobeguinii are recommended for the treatment of diarrhoea, dysentery, cholera and hypertension [6]. The root decoction is anti anthelmintic [7]. The decoction of Sarcocephalus pobeguinii stem bark is antiseptic, anti-infectious [8].

In Cameroon, in the upper valley of the Nyong forest, Sarcocephalus pobeguinii bark is used to prevent some problems of abortion [9].

\section{MATERIALS AND MeTHOdS}

\subsection{Plant Material and Preparation of the Extract}

The trunk bark of Sarcocephalus pobeguinii, harvested on the outskirts of Lambaréné in Gabon in January 2010 during the short dry season. The bark was dried in the shade and powdered. $100 \mathrm{~g}$ of powder from the bark of the trunk of Sarcocephalus pobeguinii were boiled for 15 minutes in 1000 $\mathrm{mL}$ of distilled water.

\subsection{Biological Material}

Male and female albino wistar mice and rats aged about two months and weighing 18-28 g and 160$200 \mathrm{~g}$, respectively, from the animal house of the Department of Traditional Medicine in Bamako, Mali, were used to study the acute and subchronic toxicity of the extract. These animals were acclimatised for one week before the start of the experiment and were placed 5 per cage with free access to water and food. A live human MCF-7 cancer cell line was also used.

\subsection{In Vivo Evaluation of Toxicity}

\subsubsection{Evaluation of the Acute Toxicity of the Extract of Sarcocephalus Pobeguinii}

10 mice were acclimatized for 2 weeks and fasted with free access to water for 24 hours. After the fasting period, the animals were weighed and given the extract $(2000 \mathrm{mg} / \mathrm{kg})$ by gavage and again deprived of food for 3-4 hours. The animals were observed individually at least once during the first 30 minutes after treatment. Particular attention was paid during the first 2 hours after administration. Locomotion, exploration, aggressiveness, sensitivity to touch and noise, appearance and colour of faeces and mortality or morbidity of treated animals were observed in comparison with control animals.

\subsubsection{Subchronic Toxicity of Sarcocephalus Pobeguinii Extract}

32 rats were divided into 4 batches of 4 males and 4 females each. The first batch, considered a control batch, received distilled water $(10 \mathrm{~mL} / \mathrm{kg})$; the second batch received plant extract at 10 $\mathrm{mg} / \mathrm{kg}$; the third batch was treated with extract at $50 \mathrm{mg} / \mathrm{kg}$ and the fourth batch with plant extract at $100 \mathrm{mg} / \mathrm{kg}$. The animals received a single daily dose of the extract by gavage for 13 weeks. Half of the animals were sacrificed on day 45 of treatment and the rest on day 90. The aorta, liver, heart and kidneys were removed, weighed and fixed in $10 \%$ formalin.

The arteriovenous blood was collected and left to rest for 30 minutes and then centrifuged at 3000 rpm for 5 minutes. Serum was stored at $-20^{\circ} \mathrm{C}$ for subsequent determination of alanine transaminase (ALAT) and aspartate transaminase (ASAT).

\subsection{Determination of Serum Transaminases}

$100 \mu 1$ of the sample and $500 \mu 1$ of ALAT and ASAT buffer were homogenized and incubated for 30 minutes in a water bath to which $500 \mu 1$ of the coloured reagent was added. After homogenisation and 
incubation for 20 minutes at room temperature, $5 \mathrm{ml}$ of diluted $\mathrm{NaOH}$ were added and the absorbance was read $505 \mathrm{~nm}$ against the blank. The activity of the ALAT and ASAT corresponding to the optical densities read was determined via the calibration curves of ALAT and ASAT.

\subsection{In Vitro Evaluation of Toxicity on MCF-7 Cancer Cells}

The antiproliferative potential of the extract was evaluated by microculture on the proliferation of a human MCF-7 cancer cell line. The cells were inoculated in 96-well plates at 2,104 cells per well in $200 \mu \mathrm{L}$ of culture medium for 24 hours. The cells were then treated for 48 hours with or without 0.5 and $1 \mathrm{mg} / \mathrm{mL}$ extracts in phosphate buffer solution. After $30 \mathrm{~min}$ incubation, the cells are washed with phosphate buffered saline (PBS) solution and then incubated with $0.1 \mathrm{~mL}$ MTT $(2 \mathrm{mg} / \mathrm{mL})$ for 4 hours at $37^{\circ} \mathrm{C}$. The absorbance corresponding to the solubilized Formazan crystals (reflecting the relative viability of the cell number $(\% \mathrm{~V})$ was determined at $570 \mathrm{~nm}$ with a Lasystems Multiskan MS microplate reader.

\subsection{Statistical Analyses}

The results were expressed as mean \pm ESM (standard error on the mean). Statistical analysis was performed using the analysis of variance (ANOVA) followed by Dunnett's test for comparison of the batches to each other. The probability values $\mathrm{P}<0.05$ were considered significant.

\section{RESULTS AND DiSCUSSION}

\subsection{Effects of Sarcocephalus Pobeguinii Extract 2 Hours after Administration to Mice}

It was evaluated on the behaviour and mortality rate of mice. The main behavioural responses of the mice 2 hours after gavage of a single dose of the extract are noted in Table I.

Table1. Behaviour of mice 2 hours after $2000 \mathrm{mg} / \mathrm{kg}$ of Sarcocephalus pobeguinii extract

\begin{tabular}{|c|c|c|c|c|c|c|c|}
\hline \multirow{2}{*}{$\begin{array}{ll}\text { Extract } & \text { dose } \\
(\mathrm{mg} / \mathrm{kg}) & \\
\end{array}$} & \multirow[b]{2}{*}{ Locomotion } & \multirow[b]{2}{*}{ Exploration } & \multirow[b]{2}{*}{ Agression } & \multicolumn{2}{|c|}{ Sensitivity } & \multicolumn{2}{|l|}{ Faeces } \\
\hline & & & & Touch & Noise & Appearance & Color \\
\hline $0 \mathrm{mg} / \mathrm{kg}$ & $\mathrm{N}$ & $\mathrm{N}$ & $\mathrm{N}$ & $\mathrm{N}$ & $\mathrm{N}$ & $\mathrm{G}$ & No \\
\hline $2000 \mathrm{mg} / \mathrm{kg}$ & $\mathrm{D}$ & $\mathrm{D}$ & D- & D- & $\mathrm{D}$ & $\mathrm{P}$ & $\mathrm{M}$ \\
\hline
\end{tabular}

Normal (N); Slightly diminished (D); Diminished (D-); Granular (G); Pasty (P); Black (No); Brown (M).

At $2000 \mathrm{mg} / \mathrm{kg}$, exploration, aggressiveness and sensitivity to touch and noise decreased compared to controls. Stools were pasty brown in colour. These behaviours disappeared after 2 hours of observation. There were no deaths in the mice after treatment at $2000 \mathrm{mg} / \mathrm{kg}$.

\subsection{Effects of Sarcocephalus Pobeguinii Extract on Body Weight Changes in Rats}

Figures 1 and 2 show the evolution of the body mass of male and female rats treated with different doses of the extract for 13 weeks.

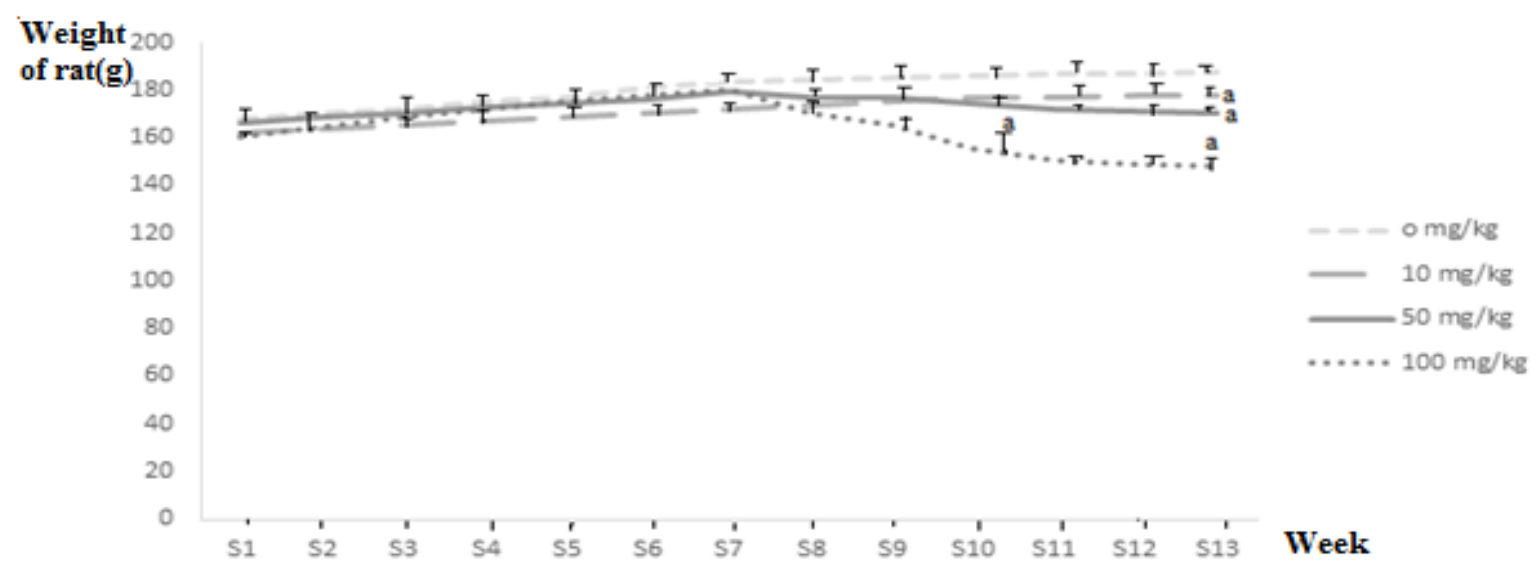

Figure1. Evolution of body weight of male rats for 13 weeks 


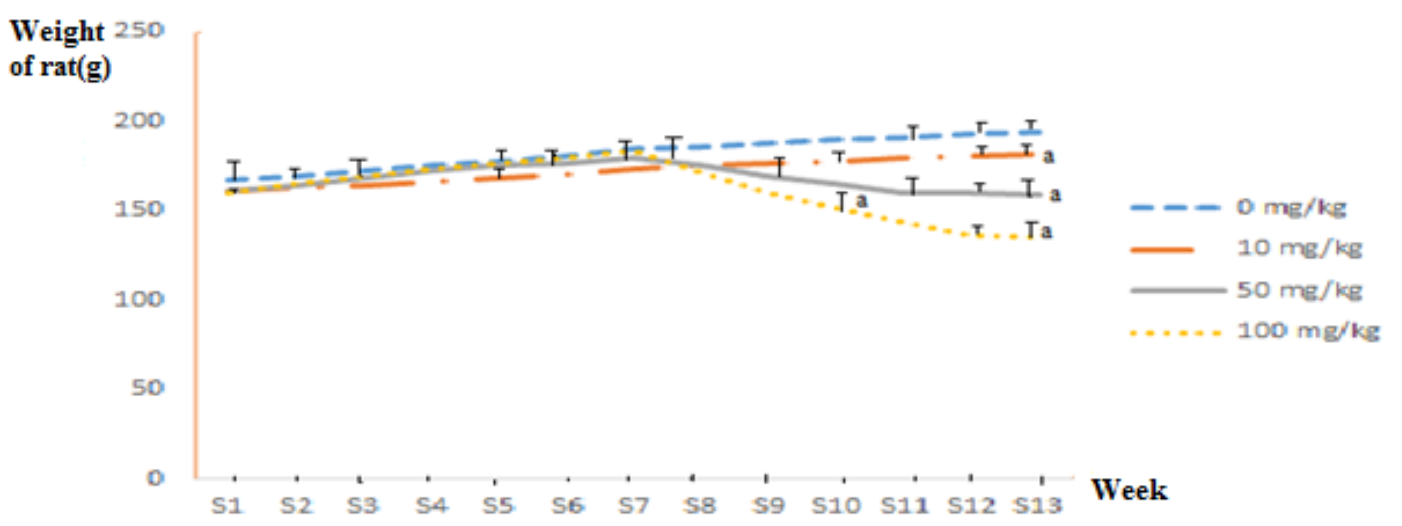

Figure2. Evolution of body weight of female rats for 13 weeks

From week eight onwards, body weight was significantly $(\mathrm{p}<0,05)$ reduced in the $100 \mathrm{mg} / \mathrm{kg}$ dose group compared to the control group. At the end of the thirteenth week, the decrease in body weight is more pronounced in the rats receiving the extract at the $100 \mathrm{mg} / \mathrm{kg}$ dose. Male rat weights were decreased by $10.40 \%$ and $26.92 \%$ for rats receiving $50 \mathrm{mg} / \mathrm{kg}$ and $100 \mathrm{mg} / \mathrm{kg}$ respectively.

\subsection{Effect of the Extract on Transaminase Activity}

Tables II and III show the effects of the extract on the activity of alanine transaminase and aspartate transaminase in animals after 45 and 90 days of treatment respectively.

Table2. Effects of the extract on the activity of ALAT and ASAT after 45 days of treatment

\begin{tabular}{|l|l|l|l|l|}
\hline & $\mathbf{0 ~} \mathbf{~ m g} / \mathbf{k g}$ & $\mathbf{1 0} \mathbf{~ m g} / \mathbf{k g}$ & $\mathbf{5 0} \mathbf{~ m g} / \mathbf{k g}$ & $\mathbf{1 0 0} \mathbf{~ m g} / \mathbf{k g}$ \\
\hline ALAT (U/I) & $60 \pm 3,51$ & $64 \pm 1,45$ & $109 \pm 2,65$ & $107 \pm 1,33$ \\
\hline ASAT (U/I) & $200 \pm 2,04$ & $235 \pm 2,85$ & $433 \pm 1,76$ & $496 \pm 1,09$ \\
\hline
\end{tabular}

The increase in ALT activity was $44.95 \%$ at the $50 \mathrm{mg} / \mathrm{kg}$ dose and $43.92 \%$ at the $100 \mathrm{mg} / \mathrm{kg}$ dose compared to control, while the increase in AST was $53.81 \%$ and $59.68 \%$ at the respective doses.

Table3. ALT and AST levels after 90 days of treatment

\begin{tabular}{|l|l|l|l|l|}
\hline & $\mathbf{0 ~} \mathbf{~ m g} / \mathbf{k g}$ & $\mathbf{1 0} \mathbf{~ m g} / \mathbf{k g}$ & $\mathbf{5 0} \mathbf{~ m g} / \mathbf{k g}$ & $\mathbf{1 0 0} \mathbf{~ m g} / \mathbf{k g}$ \\
\hline ALAT (U/I) & $51 \pm 0,23$ & $51 \pm 2,14$ & $67 \pm 1,07$ & $52 \pm 0,78$ \\
\hline ASAT (U/I) & $216 \pm 2,36$ & $219 \pm 1,98$ & $209 \pm 0,47$ & $200 \pm 1,53$ \\
\hline
\end{tabular}

ALAT activity at $50 \mathrm{mg} / \mathrm{kg}$ and $100 \mathrm{mg} / \mathrm{kg}$ increased by $23.88 \%$ and $1.92 \%$, respectively, compared to control. In contrast, the activity of AST decreased $3.24 \%$ and $8 \%$ at the respective doses.

\subsection{Effects of the Extract on Live Human Cancer Cells MCF-7}

Figure 3 shows the effects of the extract on the viability and growth of MCF-7 cells.

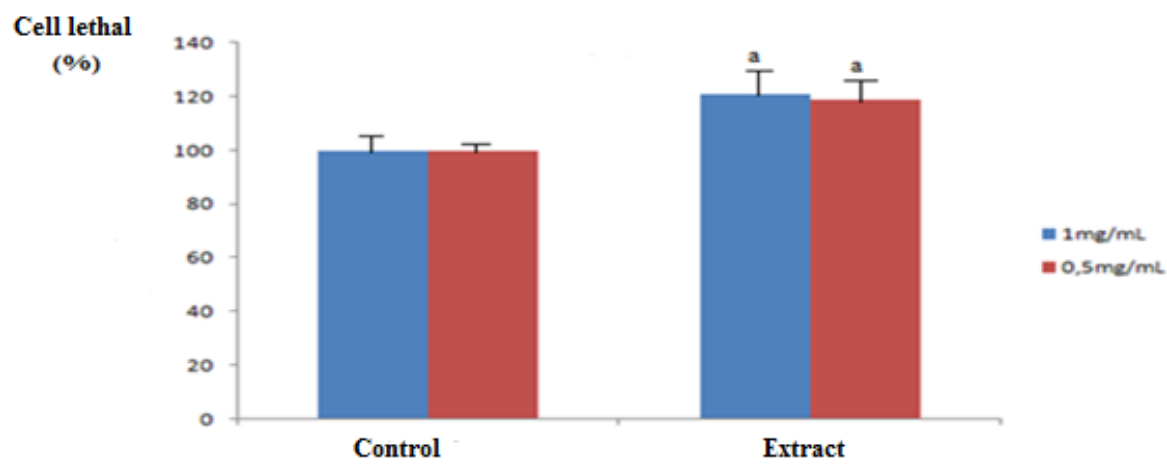

Figure3. Effects of extract on MCF-7 cells

MCF-7 cell lethal was $120 \%$ and $118 \%$ at $1 \mathrm{mg} / \mathrm{kg}$ and $0.5 \mathrm{mg} / \mathrm{kg}$, respectively, indicating no toxicity. The subchronic toxicity results show that serum transaminase activity was significantly increased, suggesting hepatic and renal impairment. In the assessment of liver damage caused by hepatotoxic substances, the determination of levels of enzymes such as ALT and AST is widely used $[10,11]$. Necrosis or membrane damage in hepatocytes results in the release of these enzymes into the 
circulation, and these enzymes can therefore be assayed in serum. Elevated levels of AST are indicative of liver, heart, and muscle disease. ALT, which is more specific to the liver, is therefore a better indicator of liver function [12]. The extract of Sarcocephalus pobeguinii caused an increase in transaminase activity. The decrease in weight more or less equally affected certain organs. A change in weight was noted in the heart and kidney and the hypertrophy observed in the liver was accentuated. This could indicate hyperactivity in the liver due to the extract. Organ hypertrophy may also be related to organ infection or inflammation, since the relative increase or decrease in weight is often a sign of underlying disease or organ damage [13]. The change in organ weight is a good indicator of toxicity after exposure to a toxic substance $[14,15]$.

The proliferation of MCF-7 cancer cells thus reflects an absence of toxicity, confirming the results of acute toxicity, from which no animal losses have been recorded. Over the last two decades, numerous studies have described the great importance of natural products in the development of new pharmaceutical products [16]. However, much work has been done on the toxic effects of natural products $[17,18]$.

\section{CONCLUSION}

The aqueous extract of the trunk bark of Sarcocephalus pobeguinii is no toxic and no carcinogenic but it requires further pharmacological studies.

\section{ACKNOWLEGEMENT}

We are very grateful to University of Sciences and Technics of Masuku, University of Mali for their funding and Issembé Yves and Niangadouma for their assistance in plant collection and identification.

\section{REFERENCES}

[1] Fleurentin, J. ; Joyeux, M. Les tests in vivo et in vitro dans l'évaluation des substances d'origine naturelle. Dans Ethnopharmacolgie : Sources, Méthodes, Objectifs. Edition ORSTOM 1990. pp 248- 257.

[2] Serrano, J.J. Toxicopharmacologie expérimentale des plantes médecinales. Actes du premier colloque Européen d'ethnopharmacologie. ORTON. 1990, pp 210-218.

[3] OMS. Lignes directrices générales pour les méthodologies de recherche et d'évaluation de la médecine traditionnelle. OMS/ EDM/TRM/1. 2000a, 27-31.

[4] Globocan. Observatoire mondial du cancer, Centre international de recherche sur le cancer, 2012.

[5] Igoli, J.O. ; Ogaji, O.G. ; Tor-anyiin, T.A. ; Igoli, N.P. Pratique de la médecine traditionnelle chez les Igede du Nigeria. Deuxième partie. African Journal of Traditional, Complementary and Alternative Medicines (2) 2005, p. 134 - 152.

[6] Baldé, N.M. ; Youla, A. ; Baldé, M.D. ; Kaké, A. ; Diallo, M.M. ; Baldé, M.A. ; Maugendré, D. Herboristerie et traitement du diabète en Afrique : un exemple en Guinée. Diabetes Metab 32, 2006, p. 171-175

[7] Kéita, S.M. ; Arnason, J.T. ; Baum, B.R. ; Marles, R. ; Camara, F. ; Traoré, A.K. Enquête ethnopharmacologique traditionnelle de certaines plantes médicinales anthelminthiques de la Haute Guinée (République de Guinée) Rév. Pharm. Afr, Vol. 13, 1999. pp 49 - 65.

[8] Magassouba, F.B. ; Diallo, A. ; Koyaté, M. ; Mara, F., Bangoura, O. ; Camara, A. ; Traoré, S. ; Diall, A.K. ; Keita, A. ; Camara, M.K. ; Barry, R. ; Keita, S. ; Oulare, K. ; Barry, M.S. ; Donzo, M. ; Camara, K.; Koté, K. ; Vanden, B.D. ; Totte, J. ; Pierters, L. Enquête ethnobotanique et activité antibactérienne de certaines plantes utilisées dans la médecine traditionnelle guinéenne. J Ethnopharmacol. Volume 114, 2007, pp. 44 - 53.

[9] Jiofack, T. ; Ayissi, I. ; Fokunang, C. ; Guedje, N. ; Kemeuze, V. Ethnobotany and phytomedicine of the upper Nyong valley forest in Cameroon African Journal of Pharmacy and Pharmacology Vol. 3(4). 2009, pp. 144-150.

[10] Dobbs, N.A. ; Twelves, C.J. ; Gregory, W. ; Cruickshanka C., Richards M.A. ; Rubens, R.D. Epirubicin in patients with liver dysfunction development and evaluation of a novel dose modification scheme. Eur. J. cancer. 39, 2003, pp580- 586.

[11] Xu, Q. ; Lu, Z. ; Zhang, X. A novel role of alcaline phosphatase in protection from immunological liver injury in mice. Foie. $22: 2002,8-14$.

[12] Williamson, J.A. ; Bosher, J.M. ; Skinner, A. ; Sheer, D. ; Williams, T. ; Hurdt, H.S. Cartographie chromosomique des homologues humains et de mousse de deux nouveaux membres de la famille des facteurs de transcription AP-2. Genomics 35 : 1996, 262 - 264. 
[13] Ijeh, I. I. ; Obidoa, O. Effect of dietary incorporation of two varieties of Vernonia amyglalna leaves on mean relative organ weights of weanling albinos rats. Niger. J. Biochem. 16, 2001, 50- 51.

[14] Raza, M. ; Alshabanah, O.A. ; Eladiyah, T.M. ; Almajied, A.A. Effect of vigabatrin treatment on haematological and biochemical parameters in plasma, liver and kidney of Swiss albino mice. Sci Pharm. 70 : 2002, 135 - 145.

[15] Téo, S. ; Strlig, D. ; Thomas, S. ; Hoberman, A. ; Kiorpes, A. ; Khetani, V. A 90 days oral gavage toxicity study of d-methylphenidate and d-l-methylphenidate in Sprague Dawley rats. Toxicol. 79 : 2002, 183-196.

[16] Patwardhan B. Ethnopharmacologie et découverte de médicaments. J Ethnopharmacol. 100, 2005, 50-52.

[17] Park, Y.K. ; Kim, J.S. ; Kang M.H. La supplémentation en jus de raisin Concord réduit la pression artérielle chez les hommes hypertendus coréens : essai d'intervention en double aveugle, contrôlé par placebo. Biofacteurs. 22, 2004, 145-147.

[18] Marcus, D.M.; Snodgrass, W.R. Do no Harm: Avoidance of herbal medicine during pregnancy. Obstet. Gynecol. v.105, n.5, 2005, pp.1119-1122.

Citation: Ousmane Kéita, et.al., (2020). Anti-Toxic and Anti-Carcinogenic Activities of the Trunk Bark of Sarcocephalus Pobeguinii. International Journal of Medicinal Plants and Natural Products (IJMPNP), 6(1), pp.22-27. http://dx.doi.org/ 10.20431 /2454-7999.0601005

Copyright: (C) 2020 Authors, this is an open-access article distributed under the terms of the Creative Commons Attribution License, which permits unrestricted use, distribution, and reproduction in any medium, provided the original author and source are credited. 